\title{
Synthesis and Density Functional Calculations of the New Molecule-Based Magnet Precursor $\left[\mathrm{Fe}\left(\mathrm{H}_{2} \mathrm{opba}-\mathrm{i}\right)(\mathrm{dmso})_{2}\right] \mathrm{Cl}$
}

\author{
Gilmar P. Souza, ${ }^{a}$ Cibele Konzen, ${ }^{b}$ José D. Ardisson, ${ }^{b}$ Heitor A. De Abreu, ${ }^{a}$ Hélio A. Duarte, ${ }^{a}$ \\ Antônio F. C. Alcântara, ${ }^{a}$ Wallace C. Nunes, ${ }^{c}$ Waldemar A. A. Macedo, ${ }^{b}$ Marcelo Knobel ${ }^{c}$ \\ and Humberto O. Stumpf ${ }^{*, a}$ \\ ${ }^{a}$ Departamento de Química, ICEx, Universidade Federal de Minas Gerais, \\ 31270-901 Belo Horizonte - MG, Brazil \\ ${ }^{b}$ Laboratório de Física Aplicada, Centro de Desenvolvimento da Tecnologia Nuclear-CDTN, CP 941, \\ 30123-970 Belo Horizonte - MG, Brazil \\ ${ }^{c}$ Instituto de Física Gleb Wataghin, Universidade Estadual de Campinas, CP 6165, \\ 13083-970 Campinas - SP, Brazil
}

\begin{abstract}
Um precursor inédito de sistemas magnéticos moleculares, $\left[\mathrm{Fe}\left(\mathrm{H}_{2}\right.\right.$ opba-i $\left.)(\mathrm{dmso})_{2}\right] \mathrm{Cl}$ (1), onde opba = orto-fenilenobis (oxamato) na forma tautomérica iminoálcool, foi obtido como produto da reação entre $\mathrm{H}_{4}$ opba e $\mathrm{FeCl}_{3}$. Os dados de análise elementar, espectroscopias de absorção no infravermelho e Mössbauer e medidas magnéticas indicam que este precursor é constituído por uma mistura de isômeros trans $(83 \%)$ e cis $(17 \%)$. O valor de $\chi_{\mathrm{M}}^{\mathrm{T}}$ a 298 $\mathrm{K}\left(2,1\right.$ emu $\left.\mathrm{K} \mathrm{mol}^{-1}\right)$ corresponde ao $\mathrm{Fe}^{\mathrm{III}}$ com estado de spin (S) entre $3 / 2$ e 5/2. Cálculos teóricos (PBE/DZVP2) de trans- e cis- $\left[\mathrm{Fe}\left(\mathrm{H}_{2} \text { opba-i }\right)(\mathrm{dmso})_{2}\right]^{+}$mostram que ambos os isômeros têm spin $\mathrm{S}=1 / 2$ no estado fundamental e $\mathrm{S}=3 / 2$ para o trans e $\mathrm{S}=5 / 2$ para o cis no primeiro estado excitado. A combinação destes resultados leva a valores de $\chi_{\mathrm{M}} \mathrm{T}$ de 0,375 emu $\mathrm{K} \mathrm{mol}^{-1}$ e 2,3 emu $\mathrm{K} \mathrm{mol}^{-1}$ a baixas e altas temperaturas, respectivamente, os quais são concordantes com os dados experimentais para $\mathbf{1}$.
\end{abstract}

A new precursor of molecule-based magnetic systems, $\left[\mathrm{Fe}\left(\mathrm{H}_{2} \mathrm{opba}-\mathrm{i}\right)(\mathrm{dmso})_{2}\right] \mathrm{Cl}(\mathbf{1})$, with opba $=$ ortho-phenylenebis(oxamato) in an iminoalcohol tautomeric form, was obtained as a product from the reaction between $\mathrm{H}_{4}$ opba and $\mathrm{FeCl}_{3}$. Data from elemental analysis, IR and Mössbauer spectroscopies and magnetic measurements indicate that this precursor is composed of a mixture of trans $(83 \%)$ and cis $(17 \%)$ isomers. The $\chi_{\mathrm{M}} \mathrm{T}$ value at $298 \mathrm{~K}\left(2.1 \mathrm{emu} \mathrm{K} \mathrm{mol}{ }^{-1}\right)$ corresponds to $\mathrm{Fe}^{\mathrm{III}}$ with spin state $(\mathrm{S})$ between $3 / 2$ and $5 / 2$. Theoretical calculations (PBE/ DZVP2) of trans- and cis-[Fe( $\mathrm{H}_{2}$ opba-i)(dmso) $\left.{ }_{2}\right]^{+}$show that both isomers have spin $\mathrm{S}=1 / 2$ in the ground state and $\mathrm{S}=3 / 2$ for the trans and $\mathrm{S}=5 / 2$ for the cis in the first excited state. The combination of these results leads to $\chi_{\mathrm{M}} \mathrm{T}$ values of 0.375 and $2.3 \mathrm{emu} \mathrm{K} \mathrm{mol}^{-1}$, at low and high temperature respectively, which are in accordance with the experimental data for $\mathbf{1}$.

Keywords: molecule-based magnet, oxamate, iron(III), PBE/DZVP theoretical calculations, cis/trans isomerism

\section{Introduction}

The oxamato-based ligands have an important role in molecular magnetism. In the seventies, the proligand 1,3propylenebis(oxamato), pba, was synthesized, and some years later it was used in the preparation of molecule-based magnets. ${ }^{1}$ In 1993 , the new precursor $\left[\mathrm{Bu}_{4} \mathrm{~N}\right]_{2}[\mathrm{Cu}($ opba) $]$,

*e-mail: stumpf@dedalus.lcc.ufmg.br opba $=$ ortho-phenylenebis(oxamato), was synthesized and largely used as a building block, due to its high solubility in common organic solvents. ${ }^{2}$

The majority of the work done with oxamato-based building blocks is with $\mathrm{Cu}^{\mathrm{II}}$, most probably due to the stability of the compounds with this metal ion. Another reason for employing this metal ion resides on the ferrimagnetic strategy, which consists in the use of two metal ions with large difference in spin states and with 
antiferromagnetic coupling. In this approach, copper complexes can bridge several metal ions resulting in extended molecular systems (chains, two- and threedimensional networks) and clusters. ${ }^{2-8}$ Such systems are recognized by their potential applications in recording/ reading magnetic systems on the molecular scale.

The opba ligand has been used for stabilization of high oxidation states of transition metal ions such as $\mathrm{Mn}^{\mathrm{III}}$ and $\mathrm{Fe}^{\mathrm{III}}$ due to the high donor capacity of the deprotonated-amide group. ${ }^{9}$ Biomimetic systems such as the dimanganese(III) complex $\left[\mathrm{PPh}_{4}\right]_{2}\left[\mathrm{Mn}_{2}(\mathrm{opba})_{2}\left(\mathrm{H}_{2} \mathrm{O}\right)_{3}\right] \cdot 3 \mathrm{H}_{2} \mathrm{O} \cdot \mathrm{MeCN}$ and the oxo-bridged diiron(III) complex $\left[\mathrm{NEt}_{4}\right]_{4}\left[\mathrm{Fe}_{2} \mathrm{O}(\text { opba })_{2}\right] \cdot 3 \mathrm{H}_{2} \mathrm{O}$ are interesting models of biological catalytic oxidations. ${ }^{20-12}$

Unlike the usual trans geometry for the $\left[\mathrm{M}^{\mathrm{x}}(\mathrm{opba})\right]^{(\mathrm{x}-4)}$ complexes, in which two deprotonated-amide nitrogen and two carboxylate oxygen atoms of the ligand form a plane, in 1997 an iron(III)-carbonate monomeric complex with a cis- $\beta$ geometry was described. This compound, $\left[\mathrm{NMe}_{4}\right]_{3}\left[\mathrm{Fe}(\mathrm{opba})\left(\mathrm{CO}_{3}\right)\right] \cdot 5 \mathrm{H}_{2} \mathrm{O}$, has been shown to be a moderately efficient catalyst for the aerobic epoxidation of alkenes with co-oxidation of pivalaldehyde. ${ }^{13}$

There is no record in the literature on extended molecular systems or clusters built with precursors containing $\mathrm{Fe}^{\mathrm{III}}$ and oxamato ligands. Furthermore, few examples of $\mathrm{Fe}^{\mathrm{III}}$ compounds coordinated simultaneously by amide nitrogen atoms and carboxylate oxygen atoms of oxamato-based ligands have been reported. ${ }^{11,13}$ The present work reports the synthesis and characterization of a new $\mathrm{Fe}^{\mathrm{IIII}}$ complex, $\left[\mathrm{Fe}\left(\mathrm{H}_{2}\right.\right.$ opba-i)(dmso) $\left.{ }_{2}\right] \mathrm{Cl}(\mathbf{1})$, with opba $=$ ortho-phenylenebis(oxamato) in an iminoalcohol tautomeric form.

\section{Experimental}

The proligand $\mathrm{H}_{4}$ opba was prepared using an adaptation of a method described elsewhere. ${ }^{2}$ All reagents were used as purchased without further purification. Elemental analyses $(\mathrm{C}, \mathrm{H}, \mathrm{N})$ were performed on a 2400 CHN-Perkin Elmer instrument. Iron content was determined on a Z-8200 Hitachi atomic absorption spectrophotometer. Infrared spectra (IR) were recorded on a Perkin-Elmer Spectrum GX FTIR spectrophotometer, using $\mathrm{KBr}$ discs. Mössbauer spectra were measured in the transmission geometry on a constant-acceleration conventional spectrometer by using a ${ }^{57} \mathrm{Co} / \mathrm{Rh}$ source and a closed cycle He cryostat. Mössbauer isomer shifts are quoted relatively to the $\alpha-\mathrm{Fe}$ at room temperature. The magnetic measurements were performed with a Quantum Design SQUID MPMS XL7 instrument. The diamagnetic correction of the sample was calculated through the constants of Pascal's constants. ${ }^{14}$
Synthesis

A solution of $\mathrm{FeCl}_{3} \cdot 6 \mathrm{H}_{2} \mathrm{O}(81.1 \mathrm{mg}, 0.30 \mathrm{mmol})$ in DMSO $(2 \mathrm{~mL})$ was added to a solution of $\mathrm{H}_{4}$ opba (75.6 $\mathrm{mg}, 0.3 \mathrm{mmol})$ in DMSO $(2 \mathrm{~mL})$. The resulting mixture was stirred at $60{ }^{\circ} \mathrm{C}$ for $1 \mathrm{~h}$ and then allowed to stand at room temperature. A methanolic solution $(10 \mathrm{~mL})$ of $\mathrm{KOH}$ (50.5 mg, $0.9 \mathrm{mmol}$ ) was then added dropwise under stirring. The solid formed was dissolved in DMSO $(8 \mathrm{~mL})$ at $60{ }^{\circ} \mathrm{C}$. The intensely brown colored solution was filtered and concentrated under reduced pressure to $4 \mathrm{~mL}$. The brown precipitate was filtered off and washed with methanol. The product was dried under reduced pressure for $4 \mathrm{~h}(79.1 \mathrm{mg}$, yield: $53 \%)$. IR $(\mathrm{KBr}) v_{\max } / \mathrm{cm}^{-1}: 3430(\mathrm{OH})$, 3127(C-H), 2900 $\left(\mathrm{CH}_{3}, \mathrm{DMSO}\right), 1695$ (amide I band), $1640(\mathrm{C}=\mathrm{O}), 1343\left(\mathrm{CH}_{3}, \mathrm{DMSO}\right), 1013(\mathrm{~S}=\mathrm{O}$, DMSO); Anal. Calc. for $\mathrm{C}_{14} \mathrm{H}_{18} \mathrm{ClFeN}_{2} \mathrm{O}_{8} \mathrm{~S}_{2} \quad(\mathrm{MM}=497.73 \mathrm{~g}$ $\mathrm{mol}^{-1}$ ): C, 33.8; H, 3.7; N, 5.6; Fe, 11.2\%. Found: C, 33.2; $\mathrm{H}, 3.4 ; \mathrm{N}, 5.8 ; \mathrm{Fe}, 12.3 \%$.

\section{Theoretical calculations}

All calculations were performed using the linear combination of Gaussian-type orbitals-Kohn-Sham density functional (LCGTO-KS-DFT) method implemented in the deMon program package. ${ }^{15}$ The exchange-correlation (XC) functional PBE was used to treat the systems; this XC functional uses the Perdew, Burke and Ernzerhof expression for exchange and correlation. ${ }^{16}$ We have used the DZVP basis set optimized explicitly for DFT by Godbout et al. ${ }^{17}$ Automatically generated auxiliary basis sets (A2) have been used for fitting the charge density. An adaptive grid with a tolerance of $10^{-6}$ for the numerical integration of the exchange-correlation and potential energy was used. ${ }^{18,19}$ All structures have been fully optimized without symmetry constraint using the standard BroydenFletcher-Goldfarb-Shanno (BFGS) method. Nonspecific solvent effects have been estimated using the united atoms Hartree-Fock/polarizable continuum model (UAHF/PCM). ${ }^{20-26}$ The solvation energies have been estimated using the Gaussian 98 program package. ${ }^{27}$ As described by Saracino et al. ${ }^{28}$ and Barone et al. ${ }^{29}$ we have used for all calculations the UAHF radii obtained by single point calculations at the $\mathrm{HF} / 6-31 \mathrm{G}(\mathrm{d}, \mathrm{p})$ level of theory using DFT optimized structures in gas phase. In the UAHF/PCM approach, the solute is placed in a polarizable cavity formed of spheres centered in the atomic groups. Inside the cavity, the dielectric constant is the same as in vacuum, and outside it takes the solvent value ( $\varepsilon=46.7$ for DMSO). 


\section{Results and Discussion}

The elemental analysis data of the product from the reaction between $\mathrm{H}_{4}$ opba and ferric chloride in $\mathrm{KOH}$ solution corresponded to the formulation $\left[\mathrm{Fe}\left(\mathrm{H}_{2} \mathrm{opba}-\mathrm{i}\right)\right.$ $\left.(\mathrm{dmso})_{2}\right] \mathrm{Cl}$. This complex presents deprotonation of both O-carboxylic atoms as in the similar reaction of $\mathrm{H}_{4} \mathrm{pba}$ with $\mathrm{KOH} .{ }^{30}$ In the literature, there are several examples of deprotonation of both oxygen and nitrogen atoms of $\mathrm{H}_{4}$ opba with copper(II), nickel(II) and manganese(II), resulting in the respective $\mathrm{M}^{\mathrm{x}}(\mathrm{opba})^{(\mathrm{x}-4)}$ compounds. ${ }^{31}$ In case of coordination with palladium(II), which affords the compound $\mathrm{Na}[\mathrm{Pd}(\mathrm{Hpba})] \cdot 2 \mathrm{H}_{2} \mathrm{O}$, the deprotonation of two $\mathrm{O}$-carboxylic and only one nitrogen atom of $\mathrm{H}_{4}$ pba has been observed. ${ }^{30}$ In fact, the present work is the first synthesis description using $\mathrm{H}_{4}$ opba that has resulted in the formation of a complex of the type $\mathrm{M}^{\mathrm{x}}\left(\mathrm{H}_{2} \mathrm{opba}\right)^{(\mathrm{x}-2)}$.

The IR data of $\mathbf{1}$ show intense absorptions at 1693 and $1640 \mathrm{~cm}^{-1}$, that can be attributed to the amide I band of secondary amides and $\mathrm{C}=\mathrm{O}$ of carboxylate groups, respectively. ${ }^{32,33}$ The frequency shifts in relation to the proligand (registered in 1775 and $1672 \mathrm{~cm}^{-1}$ ) indicate the coordination of the two nitrogen and the two O-carboxylic atoms to the $\mathrm{Fe}^{\mathrm{III}} .{ }^{34}$ The absorptions at 2913, 1013 and $1343 \mathrm{~cm}^{-1}$ (attributed to aliphatic $\mathrm{C}-\mathrm{H}$ stretching, $\mathrm{S}=\mathrm{O}$ stretching and methyl group vibrations, respectively) indicate the presence of DMSO molecules within the compound, as suggested by elemental analysis.

Figure 1 shows the ${ }^{57} \mathrm{Fe}$ Mössbauer spectrum of $\mathbf{1}$ at $70 \mathrm{~K}$, least square fitted with two doublets (Lorentzian lines). One doublet (line 1, Figure 1) presents isomer shift $\delta_{1}=0.54( \pm 0.05) \mathrm{mm} \mathrm{s}^{-1}$ and quadrupole splitting $\Delta_{1}=$ $1.33( \pm 0.04) \mathrm{mm} \mathrm{s}^{-1}$; the other doublet (line 2, Figure 1) presents isomer shift $\delta_{2}=0.52( \pm 0.05) \mathrm{mm} \mathrm{s}^{-1}$ and quadrupole splitting $\Delta_{2}=0.66( \pm 0.04) \mathrm{mm} \mathrm{s}^{-1}$. The obtained Mössbauer parameters indicate the existence of two $\mathrm{Fe}^{\mathrm{III}}$ species within the product of the reaction, in similar chemical environments. ${ }^{35,36}$ The presence of iron oxide or hydroxide in the sample is ruled out. These parameters, in addition to the IR and elemental analysis results, suggest that $\mathrm{Fe}^{\mathrm{III}}$ is in an octahedral geometry coordinated to the nitrogen and oxygen atoms of the ligand $\mathrm{H}_{2}$ opba-i. The other two coordination sites are filled with DMSO molecules. Indeed, the Mössbauer spectroscopy analysis indicates that the product of the reaction is composed of a mixture of two isomers.

According to the literature, Mössbauer spectra of octahedral complexes with trans isomers show quadrupole splittings twice as big as the ones given by complexes in the cis configuration. ${ }^{37,38}$ From these results, it can be proposed that the doublet 1 of Figure $1\left(\Delta_{1}=1.33 \mathrm{~mm}\right.$

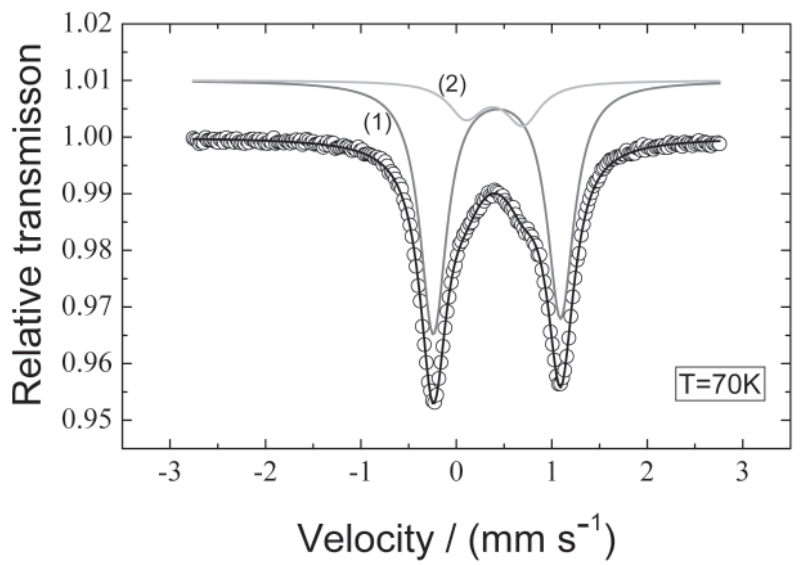

Figure 1. ${ }^{57} \mathrm{Fe}$ Mössbauer spectrum of 1 at $70 \mathrm{~K}$. Doublets 1 (solid gray line, $\delta_{1}, \Delta_{1}$ ) and 2 (light gray line, $\delta_{2}, \Delta_{2}$ ) correspond to the best fits to the experimental data (see text).
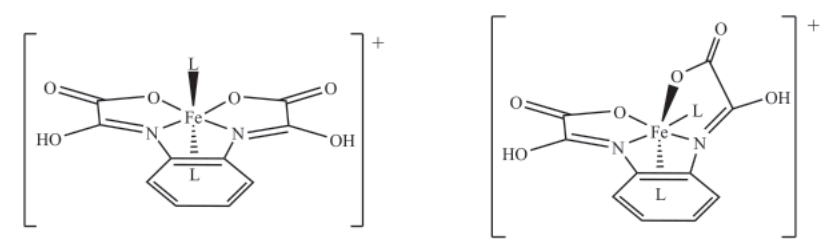

Figure 2. The trans and cis isomers of $\mathbf{1}$.

$\left.\mathrm{s}^{-1}\right)$ corresponds to the complex $\mathbf{1}$ in trans configuration, and the doublet $2\left(\Delta_{2}=0.66 \mathrm{~mm} \mathrm{~s}^{-1}\right)$ corresponds to the same complex, but in cis configuration. Moreover, from the spectral areas, it can be proposed that the reaction product contains $83 \%$ of the trans and $17 \%$ of the cis isomers of $\mathbf{1}$ shown in Figure 2.

The magnetic properties of $\mathbf{1}$ have been investigated in the 2 - $300 \mathrm{~K}$ temperature range using a polycrystalline powder. The temperature dependence of the dc magnetic susceptibility is shown in Figure 3 with a $\chi_{M} \mathrm{~T}$ versus $\mathrm{T}$ plot, $\chi_{\mathrm{M}}$ being the molar magnetic susceptibility (diamagnetic correction from Pascal's constants: -80.0 $10^{-6} \mathrm{emu} \mathrm{mol}^{-1}$ ). At room temperature $\chi_{\mathrm{M}} \mathrm{T}$ is equal to 2.1 emu $\mathrm{K} \mathrm{mol}^{-1}$. Using the spin only equation, which does not take into account either interactions among the spins or orbital contribution, the expected value of $\chi_{\mathrm{M}} \mathrm{T}$ for a $\mathrm{Fe}^{\mathrm{III}}$ ion with a low spin state $(\mathrm{S}=1 / 2)$, at room temperature, is equal to $0.375 \mathrm{emu} \mathrm{K} \mathrm{mol}^{-1} .{ }^{14}$ For the intermediate $(\mathrm{S}=3 / 2)$ and high spin $(\mathrm{S}=5 / 2)$ states, the values of $\chi_{\mathrm{M}} \mathrm{T}$ are equal to 1.875 and $4.375 \mathrm{emu} \mathrm{K} \mathrm{mol}{ }^{-1}$, respectively. Even though the isomeric shift values obtained by Mössbauer spectroscopy do not allow the determination of the spin multiplicity of $\mathbf{1}$, the experimental value of $\chi_{\mathrm{M}} \mathrm{T}$ suggests that this compound presents an $\mathrm{Fe}^{\mathrm{III}}$ spin state intermediate between $\mathrm{S}=3 / 2$ and $\mathrm{S}=5 / 2 \cdot \chi_{\mathrm{M}} \mathrm{T}$ decreases slowly as $\mathrm{T}$ is lowered until $15 \mathrm{~K}$, and then it decreases more rapidly as $\mathrm{T}$ is further 


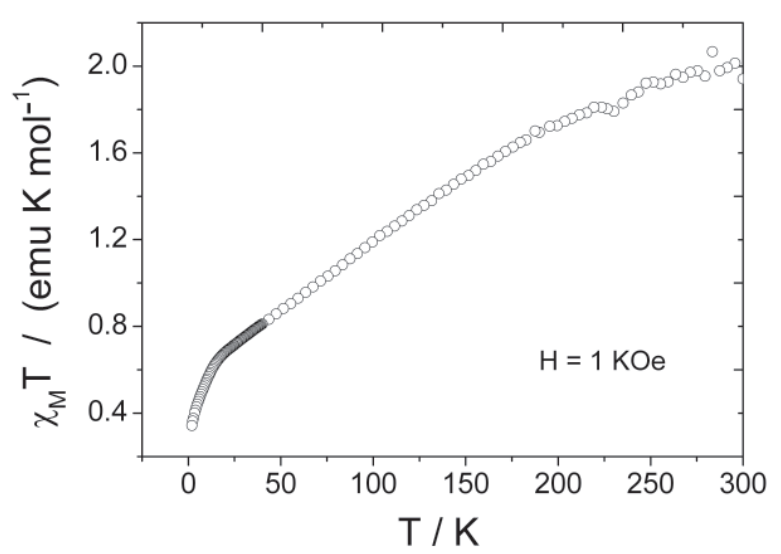

Figure 3. Temperature dependence of the product $\chi_{\mathrm{M}} \mathrm{T}$ versus temperature for $\mathbf{1}$.

lowered, reaching $0.34 \mathrm{emu} \mathrm{K} \mathrm{mol}^{-1}$ at $2 \mathrm{~K}$, the lowest available temperature. This value is approximately the one expected for a $\mathrm{Fe}^{\mathrm{III}}$ ion in a state of spin $\mathrm{S}=1 / 2$. The slight difference in the $\chi_{\mathrm{M}} \mathrm{T}$ value and the slope change below $15 \mathrm{~K}$ can be explained by intermolecular antiferromagnetic interactions.

DFT calculations have been performed aiming to provide information about the electronic structure of the isomers of $\mathbf{1}$. The functional PBE was employed since it has been successfully applied in describing transition metal systems, mainly $\mathrm{Fe}^{\mathrm{III}} .{ }^{39-41}$ Conformational analysis of the isolated $\mathrm{H}_{4}$ opba proligand was performed considering the two tautomers $\mathrm{H}_{4}$ opba (amide) and $\mathrm{H}_{4}$ opba-i (iminoalcohol) shown in Figure 4. The $\mathrm{H}_{4}$ opba tautomer is about $31.4 \mathrm{kcal} \mathrm{mol}^{-1}$ more stable than the $\mathrm{H}_{4}$ opba-i tautomer according to the DFT results. The calculated C-2,C-1,N-1',C-2' and C-1,C-2,N-1",C-2" dihedral angles are 15.2 degrees in the $\mathrm{H}_{4}$ opba tautomer. However, these dihedral angles decrease by about 6.6 degrees with the deprotonation of the carboxylic groups leading to $\mathrm{H}_{2} \mathrm{opba}^{2-}$ species. This indicates larger electronic $\pi$-delocalization in the oxamate groups, as expected.

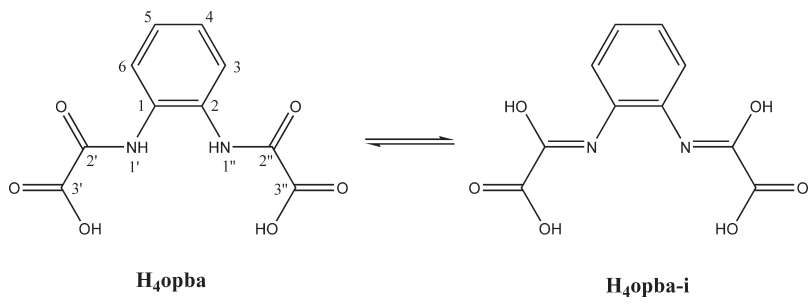

Figure 4. Amide-iminoalcohol tautomeric equilibrium involving $\mathrm{H}_{4}$ opba and $\mathrm{H}_{4}$ opba-i.

Figure 5 shows the optimized geometry for the $\left[\mathrm{Fe}\left(\mathrm{H}_{2} \mathrm{opba}-\mathrm{i}\right)\right]^{+}$complex, which presents the iminoalcohol tautomer as a ligand. The $\left[\mathrm{Fe}\left(\mathrm{H}_{2} \text { opba-i }\right)\right]^{+}$complex has $\mathrm{C}_{2 \mathrm{v}}$ symmetry with $\mathrm{Fe}-\mathrm{O}$ and $\mathrm{Fe}-\mathrm{N}$ bond distances of 1.831

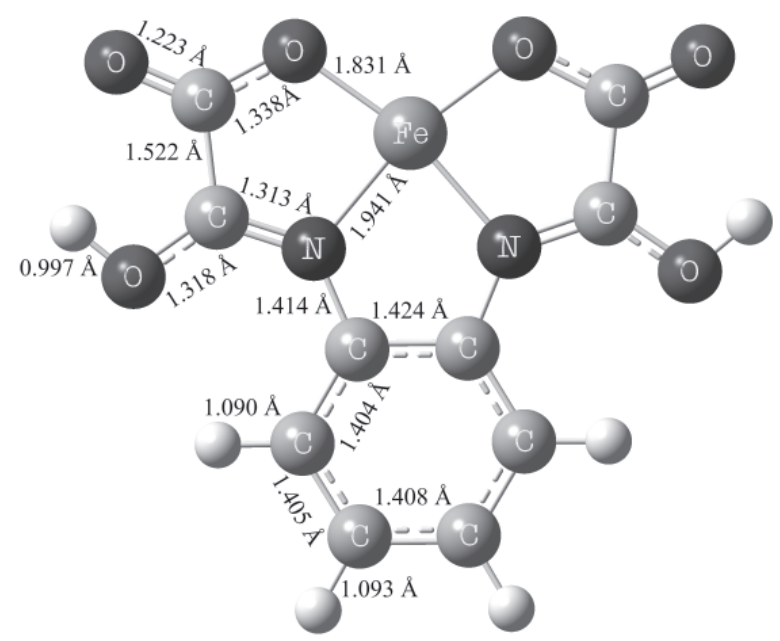

Figure 5. PBE/DZVP2 optimized geometry of $\left[\mathrm{Fe}\left(\mathrm{H}_{2} \mathrm{opba-i}\right)\right]^{+}$in the gas phase.

and $1.941 \AA$ with a quadratic planar arrangement around the iron center. Calculations showed that the amide tautomer was not a minimum in the potential energy surface, leading to the intramolecular hydrogen transfer to the O-amide. The occurrence of this type of transfer was also verified for similar systems such as $\mathrm{Na}[\mathrm{Pd}(\mathrm{Hpba})] \cdot 2 \mathrm{H}_{2} \mathrm{O}$ complex. ${ }^{30}$

According to DFT results, the ground state of $\left[\mathrm{Fe}\left(\mathrm{H}_{2} \mathrm{opba}-\mathrm{i}\right)\right]^{+}$ is a quartet $(\mathrm{S}=3 / 2)$ and the $\operatorname{doublet}(\mathrm{S}=1 / 2)$ and $\operatorname{sextet}(\mathrm{S}=5 /$ 2) lie 17.1 and $15.0 \mathrm{kcal} \mathrm{mol}^{-1}$ higher in energy, respectively. These results indicate that the $\mathrm{Fe}^{\mathrm{III}}$ ion coordinated to $\mathrm{H}_{2} \mathrm{opba-}$ $\mathrm{i}$ in the absence of dmso presents intermediary crystal-field strength with a ground state of $S=3 / 2$.

The effect of the solvent can lead to important changes in the geometry and electronic structure of metal complexes. The DMSO molecules can coordinate to the vacant sites of the iron center in the $\left[\mathrm{Fe}\left(\mathrm{H}_{2} \text { opba-i }\right)\right]^{+}$to form an octahedral complex. Figure 6 shows the optimized geometries of the cis-[Fe( $\left.\left.\mathrm{H}_{2} \mathrm{opba}-\mathrm{i}\right)(\mathrm{dmso})_{2}\right]^{+}$and trans-[ $\left.\mathrm{Fe}\left(\mathrm{H}_{2} \mathrm{opba}-\mathrm{i}\right)(\mathrm{dmso})_{2}\right]^{+}$ isomers. The optimized geometry of trans-[Fe( $\left.\mathrm{H}_{2} \mathrm{opba}-\mathrm{i}\right)$ $\left.(\mathrm{dmso})_{2}\right]^{+}$shows an octahedral surrounding containing oxamate groups in equatorial positions and the oxygen atoms of two dmso molecules in apical positions. In the case of cis$\left[\mathrm{Fe}\left(\mathrm{H}_{2} \mathrm{opba}-\mathrm{i}\right)(\mathrm{dmso})_{2}\right]^{+}$, a distorted octahedral geometry with

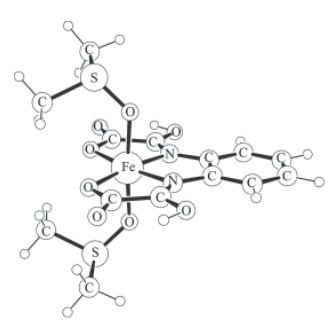

(a)

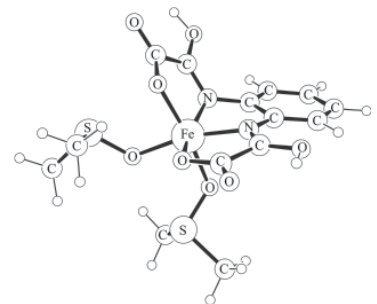

(b)
Figure 6. DFT optimized geometry for gas phase structures: (a) trans$\left[\mathrm{Fe}\left(\mathrm{H}_{2} \mathrm{opba}-\mathrm{i}\right)(\mathrm{dmso})_{2}\right]^{+}$and (b) cis-[Fe( $\left.\left.\mathrm{H}_{2} \mathrm{opba}-\mathrm{i}\right)(\mathrm{dmso})_{2}\right]^{+}$. 
the metal ion lying out of the $\mathrm{H}_{2}$ opba-i plane is observed. A similar geometry was also described for the $\left[\mathrm{NMe}_{4}\right]_{3}\left[\mathrm{Fe}(\mathrm{opba})\left(\mathrm{CO}_{3}\right)\right] \cdot 5 \mathrm{H}_{2} \mathrm{O}$ complex. ${ }^{13}$ It is important to note that for these two species we have not performed vibrational frequency calculations due to difficulties caused by the size and complexity of the system.

For the optimized geometry of the trans- $\left[\mathrm{Fe}\left(\mathrm{H}_{2} \mathrm{opba}-\mathrm{i}\right)\right.$ (dmso) $\left.]_{2}\right]^{+}$configuration (Figure 6 ), the spin states $\mathrm{S}=1 / 2$, $3 / 2$, and $5 / 2$ were considered. The calculated ground state is the doublet $(\mathrm{S}=1 / 2)$; the quartet $(\mathrm{S}=3 / 2)$ and sextet $(\mathrm{S}=5 / 2)$ states lie 7.5 and $10.7 \mathrm{kcal} \mathrm{mol}^{-1}$ higher in energy, respectively. For $c i s-\left[\mathrm{Fe}\left(\mathrm{H}_{2} \text { opba-i }\right)(\mathrm{dmso})_{2}\right]^{+}$, the quartet $(\mathrm{S}=3 / 2)$ and sextet $(\mathrm{S}=5 / 2)$ lie 7.8 and $5.2 \mathrm{kcal} \mathrm{mol}^{-1}$ higher in energy, respectively, showing inversion of the relative stability of the quartet and sextet states compared to trans- $\left[\mathrm{Fe}\left(\mathrm{H}_{2} \text { opba-i }\right)(\mathrm{dmso})_{2}\right]^{+}$. These results are in accordance with the low temperature magnetic properties and $\chi_{\mathrm{M}} \mathrm{T}$ value of $0.34 \mathrm{emu} \mathrm{K} \mathrm{mol}{ }^{-1}$, corresponding to a $\mathrm{S}=1 / 2$ ground state. The $c i s-\left[\mathrm{Fe}\left(\mathrm{H}_{2} \text { opba-i }\right)(\mathrm{dmso})_{2}\right]^{+}$is the most stable and trans- $\left[\mathrm{Fe}\left(\mathrm{H}_{2} \text { opba-i }\right)(\mathrm{dmso})_{2}\right]^{+}$is about 5.7 kcal mol ${ }^{-1}$ higher in energy.

One could argue that the magnetic property observed for this system is the average of the $\chi_{M} T$ of the two distinct complexes observed in the Mössbauer data. In order to test this hypothesis, it was assumed that, at room temperature, the low lying states $\mathrm{S}=3 / 2$ for trans$\left[\mathrm{Fe}\left(\mathrm{H}_{2} \text { opba-i }\right)(\text { dmso })_{2}\right]^{+}$(calculated $\chi_{\mathrm{M}} \mathrm{T}$ equal to 1.875 emu $\left.\mathrm{K} \mathrm{mol}^{-1}\right)$ and $\mathrm{S}=5 / 2$ for cis- $\left[\mathrm{Fe}\left(\mathrm{H}_{2} \text { opba-i }\right)(\mathrm{dmso})_{2}\right]^{+}$

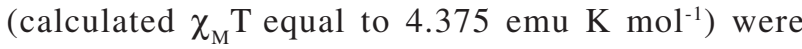
populated. Combining these values with the Mössbauer data, which indicates an $83 \%$ occurrence of the trans isomer and $17 \%$ of the cis isomer, a $\chi_{\mathrm{M}} \mathrm{T}$ value can be proposed as a weighted average as follows: $\chi_{\mathrm{M}} \mathrm{T}=(0.83 \mathrm{x}$ $1.875+0.17 \times 4.375)=2.3 \mathrm{emu} \mathrm{K} \mathrm{mol}^{-1}$. This value decreases if it is admitted that the $\mathrm{S}=3 / 2$ state is also populated for the cis isomer. This value of the product $\chi_{\mathrm{M}} \mathrm{T}$ is close to that measured at room temperature for the compound $\mathbf{1}$.

\section{Conclusions}

We have shown an efficient methodology for the preparation of a new precursor of a molecule-based magnet containing $\mathrm{Fe}^{\mathrm{III}},\left[\mathrm{Fe}\left(\mathrm{H}_{2} \mathrm{opba}\right)(\mathrm{dmso})_{2}\right] \mathrm{Cl}$ (1). The investigation of its physical and chemical properties was carried out by analysis of experimental data (elemental analysis, Mössbauer spectroscopy and magnetic susceptibility measurements) combined with results obtained by theoretical calculations. These results indicate that the reaction product presents a mixture of trans and cis isomers in relation to the two DMSO molecules. DFT conformational analysis was performed on the proligand and the complex with iron(III), providing information about cis/trans isomerism, tautomerism, coordination site preference and spin states. The ground state found in the calculations for the two isomers was $S=1 / 2$, in agreement with the magnetic properties at low temperatures. The calculations, Mössbauer and magnetic studies of $\mathbf{1}$ led to the interpretation of its magnetic properties based on a conversion of spin. Another natural hypothesis for the decreasing of $\chi_{\mathrm{M}} \mathrm{T}$ from the room temperature value is the establishment of antiferromagnetic interactions. However, this is less probable, since such interactions should be very strong at room temperature where a value of 4.375 emu K mol${ }^{-1}$ would be expected (considering $\mathrm{S}=5 / 2$ ). In the other extreme, we can suppose a spin state of $S=1 / 2$ with orbital contribution for the magnetic moment and a vanishing of this later with the temperature, but in this case an overestimated orbital contribution should be adopted.

Finally, it is worth emphasizing that $\mathbf{1}$ is soluble in DMSO and DMF, which is an important property for reactions with other metal ions in the preparation of clusters or extended molecule-based magnets.

\section{Acknowledgments}

The authors would like to thank the support of Conselho Nacional de Desenvolvimento Científico e Tecnológico (CNPq), Coordenação de Aperfeiçoamento de Pessoal de Nível Superior (CAPES), Fundação de Amparo à Pesquisa do Estado de Minas Gerais (FAPEMIG) and Fundação de Amparo à Pesquisa do Estado de São Paulo (FAPESP).

\section{References}

1. Nonoyama, K.; Ojima, H.; Nonoyama, M.; Inorg. Chim. Acta 1976, 20, 12.

2. Stumpf, H. O.; Pei, Y.; Kahn, O.; Sletten, J.; Renard, J. P.; J. Am. Chem. Soc. 1993, 115, 6738.

3. Kahn, O.; Pei, Y.; Sletten, J.; J. Am. Chem. Soc. 1986, 108, 3143.

4. Pereira, C. L. M.; Pedroso, E. F.; Stumpf, H. O.; Novak, M. A.; Ricard, L.; Ruiz-Garcia, R.; Riviere, E.; Journaux, Y.; Angew. Chem., Int. Ed. 2004, 43, 956.

5. Vaz, M. G. F.; Knobel, M.; Speziali, N. L.; Moreira, A. M.; Alcântara, A. F. C.; Stumpf, H. O.; J. Braz. Chem. Soc. 2002, 13, 183.

6. Cador, O.; Vaz, M. G. F.; Stumpf, H. O.; Mathonière, C.; Kahn, O.; Synth. Met. 2001, 122, 559. 
7. Sessoli, R.; Gatteschi, D.; Caneschi, A.; Novak, M. A.; Nature 1993, 365, 141.

8. Pardo, E.; Morales-Osorio, I.; Julve, M.; Lloret, F.; Cano, J.; Ruiz-García, R.; Pasán, J.; Ruiz-Pérez, C.; Ottenwaelder, X.; Journaux, Y.; Inorg. Chem. 2004, 43, 7594.

9. Ruiz, R.; Surville-Barland, C.; Aukauloo, A.; AnxolabehereMallart, E.; Journaux, Y.; Cano, J.; Muñoz, M. C.; J. Chem. Soc., Dalton Trans. 1997, 745.

10. Blay, G.; Fernández, I.; Giménez, T.; Pedro, J. R.; Ruiz, R.; Pardo, E.; Lloret, F.; Muñoz, M. C.; Chem. Commun. 2001, 2102.

11. Pardo, E.; Lloret, F.; Carrasco, R.; Muñoz, M. C.; TemporalSànchez, T.; Ruiz-Garcia, R.; Inorg. Chim. Acta 2004, 357, 2713.

12. Lippard, S. J.; Angew. Chem., Int. Ed. 1988, 27, 344.

13. Ruiz, R.; Triannidis, M.; Aukauloo, A.; Journaux, Y.; Fernández, I.; Pedro, J. R.; Cervera, B.; Castro, I.; Muñoz, M. C.; Chem. Commun. 1997, 2283.

14. Earnshaw, A.; Introduction to Magnetochemistry; Academic Press: New York, 1968.

15. Koester, A. M.; Flores, R.; Geudtner, G.; Goursot, A.; Heine, T.; Patchkovskii, A. M.; Reveles, J. U.; Vela, A.; Salahub, D.; Program deMon, version 1.1.0; NRC: Ottawa, Canada, 2004.

16. Perdew, J. P.; Burke, K.; Ernzerhof, M.; Phys. Rev. Lett. 1996, 77, 3865.

17. Godbout, N.; Salahub, D. R.; Andzelm, J.; Wimmer, E.; Can. J. Chem. Rev. 1992, 70, 560.

18. Krack, M.; Koster, A. M.; J. Chem. Phys. 1998, 108, 3226.

19. Koster, A. M.; Flores-Moreno, R.; Reveles, J. U.; J. Chem. Phys. 2004, 121, 681.

20. Fletcher, R.; Comput. J. 1970, 13, 317.

21. Broyden, C. G.; J. Inst. Math. Appl. 1970, 6, 76.

22. Goldfarb, D.; Math. Comp. 1970, 24, 23.

23. Shanno, D. F.; Math. Comp. 1970, 24, 647.

24. Broyden, C. G.; J. Inst. Math. Appl. 1970, 6, 222.

25. Cossi, M.; Barone, V.; Cammi, R.; Tomasi, J.; J. Chem. Phys. Lett. 1996, 255, 327.

26. Tomasi, J.; Persico, M.; Chem. Rev. 1994, 94, 2027.

27. Frisch, M. J.; Trucks, G. W.; Schlegel, H. B.; Scuseria, G. E.; Robb, M. A.; Cheeseman, J. R.; Zakrzewski, V. G.; Montgomery, J.; Stratmann, R. E.; Burant, J. C.; Dapprich, S.; Millam, J. M.; Daniels, A. D.; Kudin, K. N.; Strain, M. C.;
Farkar, O.; Tomasi, J.; Barone, V.; Cossi, M.; Cammi, R.; Mennucci, B.; Pomelli, C.; Adamo, C.; Clifford, S.; Ochterski, J.; Petersson, G. A.; Ayala, P.Y.; Cui, Q.; Morokuma, K.; Malick, D. K.; Rabuck, A. D.; Raghavachari, K.; Foresman, J. B.; Cioslowski, J.; Ortiz, J. V.; Stefanov, B. B.; Liu, G.; Liashenko, A.; Piskorz, P.; Komaromi, I.; Gomperts, R.; Martin, R. L.; Fox, D. J.; Keith, T.; Al-Laham, M. A.; Peng, C. Y.; Nanayakkara, A.; Gonzalez, C.; Challacombe, M.; Gill, P. M. W.; Johnson, B.; Chen, W.; Wong, M. W.; Andres, J. L.; Gonzalez, C.; Head-Gordon, M.; Replogle, E. S.; Pople, J. A; Gaussian; Gaussian, Inc.: Pittsburgh PA, 1998.

28. Saracino, G. A. A.; Improta, R.; Barone, V.; Chem. Phys. Lett. 2003, 373, 411.

29. Barone, V.; Cossi, M.; Tomasi, J.; J. Chem. Phys. 1997, 107, 3210 .

30. Kivekas, R.; Pajunem, A.; Navarrete, A.; Colacio, E.; Inorg. Chim. Acta 1999, 284, 292.

31. Fettouhi, M.; Ouahab, L.; Boukhari, A.; Cador, O.; Mathonière, C.; Kahn, O.; Inorg. Chem. 1996, 35, 4932.

32. Nakamoto, K.; Infrared Spectra of Inorganic and Coordination Compounds, John Wiley: New York, 1963.

33. Colthup, N. B.; Daly, L. H. ; Wiberley, S. E.; Introduction to Infrared and Raman Spectroscopy, Academic Press: New York, 1964.

34. Nonoyama, M.; Ojima, H.; Ohki, K.; Nonoyama, K.; Inorg. Chim. Acta 1980, 41, 155.

35. Greenwood, N. N.; Gibb, T. C.; Mössbauer Spectroscopy, Chapman and Hall: London, 1971.

36. Bancroft, G. M.; Mössbauer Spectroscopy: An Introduction for Inorganic Chemists and Geochemists, McGraw-Hill: London, 1973.

37. Berrett, R. R.; Fitzsimmons, B. W.; Chem Comm. 1966, 91.

38. Berrett, R. R.; Fitzsimmons, B. W.; J. Chem. Soc. 1967, A, 525.

39. De Abreu, H. A.; Guimarães, L.; Duarte, H. A.; J. Phys. Chem. A 2006, 110, 7713.

40. Rotzinger, F. P.; J. Phys. Chem. B 2005, 109, 1510.

41. Cotton, F. A.; Daniels, L. M.; Murillo, C. A.; Quesada, J. F.; Inorg. Chem. 1993, 32, 4861.

Received: June 12, 2006

Published on the web: December 1, 2006

FAPESP helped in meeting the publication costs of this article. 